\title{
Molecular evolution of Azagny virus, a newfound hantavirus harbored by the West African pygmy shrew (Crocidura obscurior) in Côte d'Ivoire
}

\author{
Hae Ji Kang ${ }^{1}$, Blaise Kadjo ${ }^{2}$, Sylvain Dubey ${ }^{3}$, François Jacquet ${ }^{4}$ and Richard Yanagihara ${ }^{1 *}$
}

\begin{abstract}
Background: Tanganya virus (TGNV), the only shrew-associated hantavirus reported to date from sub-Saharan Africa, is harbored by the Therese's shrew (Crocidura theresae), and is phylogenetically distinct from Thottapalayam virus (TPMV) in the Asian house shrew (Suncus murinus) and Imjin virus (MJNV) in the Ussuri white-toothed shrew (Crocidura lasiura). The existence of myriad soricid-borne hantaviruses in Eurasia and North America would predict the presence of additional hantaviruses in sub-Saharan Africa, where multiple shrew lineages have evolved and diversified.
\end{abstract}

Methods: Lung tissues, collected in RNAlater ${ }^{\circledR}$, from 39 Buettikofer's shrews (Crocidura buettikoferi), 5 Jouvenet's shrews (Crocidura jouvenetae), 9 West African pygmy shrews (Crocidura obscurior) and 21 African giant shrews (Crocidura olivieri) captured in Côte d'Ivoire during 2009, were systematically examined for hantavirus RNA by RTPCR.

Results: A genetically distinct hantavirus, designated Azagny virus (AZGV), was detected in the West African pygmy shrew. Phylogenetic analysis of the $S, M$ and $L$ segments, using maximum-likelihood and Bayesian methods, under the GTR $+1+\Gamma$ model of evolution, showed that AZGV shared a common ancestry with TGNV and was more closely related to hantaviruses harbored by soricine shrews than to TPMV and MJNV. That is, AZGV in the West African pygmy shrew, like TGNV in the Therese's shrew, did not form a monophyletic group with TPMV and MJNV, which were deeply divergent and basal to other rodent- and soricomorph-borne hantaviruses. Ancestral distributions of each hantavirus lineage, reconstructed using Mesquite 2.74, suggested that the common ancestor of all hantaviruses was most likely of Eurasian, not African, origin.

Conclusions: Genome-wide analysis of many more hantaviruses from sub-Saharan Africa are required to better understand how the biogeographic origin and radiation of African shrews might have contributed to, or have resulted from, the evolution of hantaviruses.

\section{Background}

Sub-Saharan Africa has long been considered the "birthplace" of many medically important vector-borne and zoonotic viruses. Among myriad examples are human immunodeficiency virus type 1 , which resulted from multiple cross-species transmissions among nonhuman primates to become well established in humans [1,2]; Ebola virus, a filovirus harbored by fruit bats $[3,4]$, which is among the deadliest viruses on earth; and

\footnotetext{
* Correspondence: yanagiha@pbrc.hawaii.edu

'John A. Burns School of Medicine, University of Hawaii at Manoa, Honolulu, HI 96813, USA

Full list of author information is available at the end of the article
}

Lassa virus, a rodent-borne arenavirus [5], which causes an estimated 100,000-500,000 human infections each year in West African countries. In addition, the recent report of Lujo virus as the cause of fatal hemorrhagic fever in South Africa [6], where severe arenavirus-associated human disease had not been previously recognized, serves as a startling reminder that other pathogenic zoonotic viruses remain undiscovered.

While rodents (Order Rodentia) have long been known to serve as reservoirs of hantaviruses (Family Bunyaviridae, Genus Hantavirus), recent studies indicate a far richer genetic diversity among hantaviruses harbored by shrews (Order Soricomorpha, Family 
Soricidae) and moles (Family Talpidae) of multiple species spanning across four continents, including Thottapalayam virus (TPMV) in the Asian house shrew (Suncus murinus) $[7,8]$, Imjin virus (MJNV) in the Ussuri white-toothed shrew (Crocidura lasiura) [9], Cao Bang virus (CBNV) in the Chinese mole shrew (Anourosorex squamipes) [10], Seewis virus (SWSV) in the Eurasian common shrew (Sorex araneus) [11,12], Ash River virus (ARRV) in the masked shrew (Sorex cinereus) and Jemez Spring virus (JMSV) in the dusky shrew (Sorex monticolus) [13], Kenkeme virus (KKMV) in the flatskulled shrew (Sorex roboratus) [14], Camp Ripley virus (RPLV) in the northern short-tailed shrew (Blarina brevicauda) [15], Asama virus (ASAV) in the Japanese shrew mole (Urotrichus talpoides) [16], Oxbow virus (OXBV) in the American shrew mole (Neurotrichus gibbsii) [17], Nova virus (NVAV) in the European common mole (Talpa europaea) [18] and Rockport virus (RKPV) in the eastern mole (Scalopus aquaticus) [19]. Until recently, conspicuous in their absence have been reports of hantaviruses in Africa. Sangassou virus (SANV) in the African wood mouse (Hylomyscus simus) [20] and Tanganya virus (TGNV) in the Therese's shrew (Crocidura theresae) [21] are the only known examples to date, but additional hantaviruses likely exist in subSaharan Africa, where unique rodent and soricid lineages have evolved and diversified.

In this study, lung tissues from crocidurine shrews captured in Côte d'Ivoire were systematically analyzed for hantavirus RNA by reverse transcription polymerase chain reaction (RT-PCR). Undaunted by the vast genetic diversity of hantaviruses harbored by shrews, we resorted to a brute-force strategy of designing oligonucleotide primers based on regions of high sequence conservation. After exhaustive hit-and-miss attempts, a genetically distinct hantavirus, designated Azagny virus (AZGV), was detected in the West African pygmy shrew (Crocidura obscurior). Sequence and phylogenetic analyses of the $\mathrm{S}, \mathrm{M}$ and $\mathrm{L}$ segments indicated that AZGV shared a common ancestry with TGNV and was evolutionarily distant from TPMV and MJNV, two crocidurine shrew-borne hantaviruses in Asia.

\section{Methods}

\section{Trapping and specimen collection}

Shrews were live caught, using pitfall traps, as well as Sherman traps $(8 \times 9 \times 23 \mathrm{~cm})($ H.B. Sherman, Tallahassee, FL) and Longworth traps $(14 \times 6.5 \times 8.5 \mathrm{~cm})$ (Penlon Ltd., Oxford, UK). Pitfall traplines were set with drift fences using 1-m plastic sheeting or fine mesh cloth erected between short poles and running across plastic buckets that were $20-\mathrm{cm}$ deep and buried flush with the soil surface. Up to 20 buckets were placed along 100 - to $150-\mathrm{m}$ long drift fences at $5-$ to $10-\mathrm{m}$ intervals. Sherman and Longworth traps were set at intervals of $5 \mathrm{~m}$ during daylight hours of each day. Trapping was conducted over two to 10 consecutive days, at Azagny National Park, Lamto Natural Reserve and Dabou (Figure 1), during March, July, August, November and December 2009. Traplines and pitfalls were checked every morning and coordinates of each trapped animal were recorded by the global positioning system (GPS). Species, gender, weight, reproductive maturity and GPS coordinates of each captured shew were recorded. Lung tissues were collected in RNAlater ${ }^{\circledR}$ RNA Stabilization Reagent (Qiagen, Inc., Chatsworth, CA) and processed for RNA extraction, within 4 weeks of collection, for RT-PCR analysis. All experimental procedures on animals followed internationally recognized guidelines and were approved by the Ivorian National Park Office and the Muséum National d'Histoire Naturelle.

\section{RNA extraction and CDNA synthesis}

Total RNA was extracted, using the PureLink Micro-toMidi total RNA purification kit (Invitrogen, San Diego, CA), from shrew tissues, and cDNA was prepared using

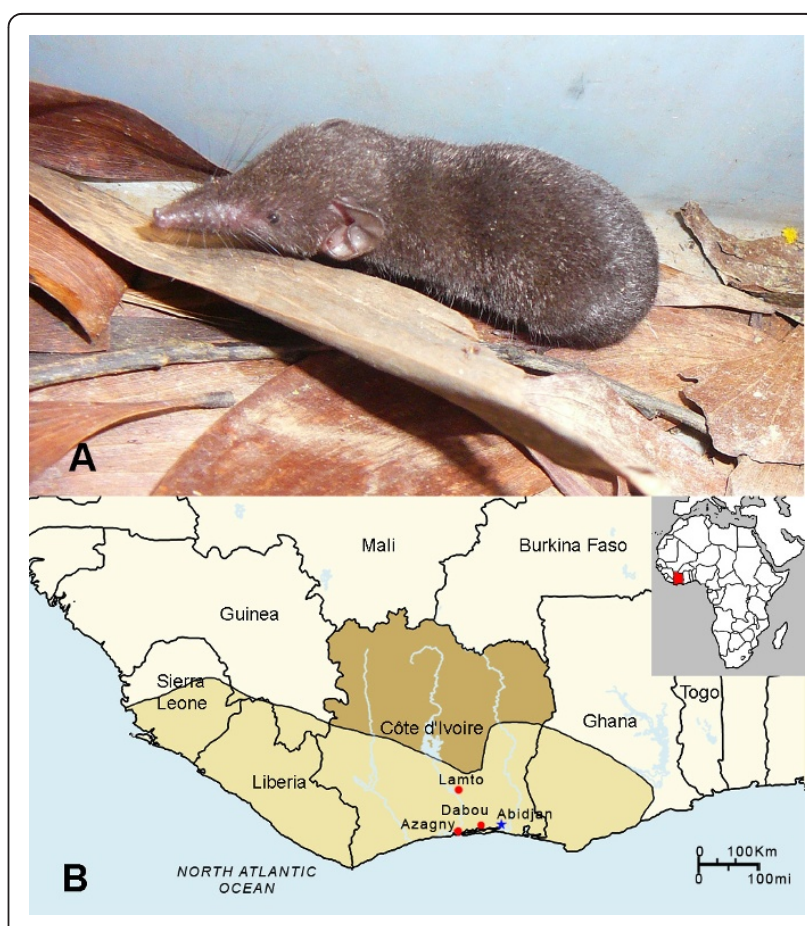

Figure 1 West African pygmy shrew and geographic distribution. (A) Crocidura obscurior (West African pygmy shrew). (B) Map of Côte d'Ivoire, showing sites where crocidurine shrews were captured in 2009, particularly Azagny National Park, where a West African pygmy shrew harboring a newfound hantavirus was captured. The geographic range of the West African pygmy shrew extends along the coast of Côte d'Ivoire and neighboring Ghana, Guinea, Liberia and Sierra Leone (shaded area). 
the SuperScript III First-Strand Synthesis System (Invitrogen) and random hexamers and/or an oligonucleotide primer (OSM55: 5'-TAGTAGTAGACTCC-3') designed from the conserved 5'-end of the $\mathrm{S}, \mathrm{M}$ and $\mathrm{L}$ segments of hantaviruses.

\section{RT-PCR and DNA sequencing}

PCR was performed as described previously [18], with each $20-\mu \mathrm{L}$ reaction containing $250 \mu \mathrm{M}$ dNTP, $2 \mathrm{mM}$ $\mathrm{MgCl}_{2}, 1 \mathrm{U}$ of AmpliTaq polymerase (Roche, Basel, Switzerland) and $0.25 \mu \mathrm{M}$ of oligonucleotide primers, with trial-and-error testing of primers and modified cycling conditions. Initial denaturation at $94^{\circ} \mathrm{C}$ for $5 \mathrm{~min}$ was followed by two cycles each of denaturation at $94^{\circ} \mathrm{C}$ for 40 sec, two-degree step-down annealing from $48^{\circ} \mathrm{C}$ to $38^{\circ} \mathrm{C}$ for $40 \mathrm{sec}$, and elongation at $72^{\circ} \mathrm{C}$ for $1 \mathrm{~min}$, then 32 cycles of denaturation at $94^{\circ} \mathrm{C}$ for $40 \mathrm{sec}$, annealing at $42^{\circ}$ $\mathrm{C}$ for $40 \mathrm{sec}$, and elongation at $72^{\circ} \mathrm{C}$ for $1 \mathrm{~min}$, in a GeneAmp PCR 9700 thermal cycler (Perkin-Elmer, Waltham, MA). Amplicons were purified using the QIAQuick Gel Extraction Kit (Qiagen, Hilden, Germany), and DNA sequencing was performed using an ABI Prism 377XL Genetic Analyzer (Applied Biosystems, Foster City, CA).

\section{Protein analysis and secondary structure prediction}

For secondary structure prediction of the nucleocapsid protein and envelope glycoprotein, amino acid sequences were submitted to NPS@ structure server [22]. Glycosylation sites and transmembrane helices were predicted using NetNlyc 1.0 and Predictprotein [23] and TMHMM version 2.0 [24], respectively.

\section{Phylogenetic analysis}

Partial S-, M- and L-segment sequences of AZGV were aligned and compared with publicly available hantavirus sequences, using ClustalW (DNASTAR, Inc., Madison, WI) [25] and transAlign [26]. Representative members of the Nairovirus (Dugbe virus, NC_004157) and Phlebovirus (Rift Valley fever virus, NC_014395) genera were included as outgroups. Phylogenetic trees were generated by maximum likelihood and Bayesian methods, implemented in PAUP* (Phylogenetic Analysis Using Parsimony, 4.0b10) [27], RAxML Blackbox webserver [28] and MrBayes 3.1 [29], under the best-fit GTR $+\mathrm{I}+\Gamma$ model of evolution established using jModeltest 0.1.1 [30]. By employing two complementary and not redundant ML methods, additional analytical rigor was achieved. Topologies were evaluated by bootstrap analysis of 1,000 iterations, and posterior node probabilities were based on 2 million generations and estimated sample sizes over 100 (implemented in MrBayes). Since tree topologies for each genomic segment were very similar using RAxML, PAUP* and MrBayes, trees generated by MrBayes were displayed.

\section{Biogeographic analyses}

Ancestral distributions of each lineage were reconstructed using a maximum-likelihood approach using Mesquite 2.74 [31]. The current geographic distribution of hantavirus species was coded as 0 for Eurasia, 1 for Africa, and 2 for America. Similarly, we tested for an ancestral Soricomorpha (0) vs. Rodentia (1) origin of hantaviruses. The model of character evolution was a simple stochastic model (Mk1) [32], which assumed an equal and symmetrical rate of change between any two states $[33,34]$, and the character state frequencies were estimated from the transition probabilities. In this likelihood-based approach, the probability that a character changes along a branch of the tree is consequently a function of the branch length, with changes being less likely along shorter branches than longer ones.

To have branch lengths representing absolute time of divergence, a calibrated Bayesian tree was built with BEAST 1.4 [35] using a Yule tree prior (adequate to study interspecific diversification). Preliminary analyses were performed with an uncorrelated lognormal relaxed clock to test if a strict molecular clock can be rejected for our dataset (ucld.stdev parameter with a frequency histogram abutting 0). Because in our simulations the "ucld.stdev" had a frequency histogram not abutting 0 , we chose this molecular clock for the analyses [36]. The analyses were performed with two independent chains and 10 million generations and chains were sampled every 1,000 generations with a burn-in of 1 million generations. Convergences were determined with Tracer v1.4 [37].

\section{mtDNA sequence analysis}

The entire 1,140-nucleotide region of the cytochrome $b$ gene of mtDNA was amplified by PCR, as previously described $[17,18]$, to confirm the taxonomic identity of the hantavirus-infected shrew and to examine its phylogenetic relationship to other shrew hosts.

\section{Results and Discussion}

RT-PCR and sequence analysis

In analyzing lung tissues from 39 Buettikofer's shrews (Crocidura buettikoferi), 5 Jouvenet's shrews (Crocidura jouvenetae), 9 West African pygmy shrews (Crocidura obscurior) and 21 African giant shrews (Crocidura olivieri) by RT-PCR using multiple primer pairs, novel hantavirus RNAs were detected in a West African pygmy shrew, captured in Azagny National Park (latitude, $5^{\circ} 14.5^{\prime} \mathrm{N}$; longitude, $\left.4^{\circ} 48.1^{\prime} \mathrm{W}\right)$, Côte d'Ivoire, on December 15, 2009 (Figure 1). The identity of the West African pygmy shrew (GenBank JF276229), in which AZGV was detected, was confirmed by phylogenetic analysis of the 1,140-nucleotide mtDNA cytochrome $b$ gene (results not shown). 
Although hantavirus RNAs were not found in tissues of the other three African crocidurine shrew species tested, we believe it is simply because suitable oligonucleotide primers were not designed. This conjecture is based on our past experience of repeated failed attempts before the successful detection of soricomorph-borne hantaviruses [17-19]. Thus, continuing efforts are ongoing to retest these specimens, and future expeditions are being planned to collect tissues suitable for virus isolation attempts.

Despite intensive efforts to obtain the full genome of AZGV, the inability to effectively design primers for this novel hantavirus and the limited amount of available RNA were obstacles too great to overcome. Nevertheless, pairwise alignment and comparison of partial S-, $\mathrm{M}$ - and L-genomic segment sequences of AZGV with representative rodent- and soricid-borne hantaviruses clearly demonstrated that AZGV was genetically distinct (Table 1). AZGV was most closely related to TGNV

\begin{tabular}{|c|c|c|c|c|c|c|}
\hline \multirow[b]{2}{*}{ Virus strain } & \multicolumn{2}{|c|}{ S segment } & \multicolumn{2}{|c|}{ M segment } & \multicolumn{2}{|c|}{ L segment } \\
\hline & $\begin{array}{c}540 \\
\mathrm{nt}\end{array}$ & $\begin{array}{c}180 \\
\text { aa }\end{array}$ & $\begin{array}{c}687 \\
\mathrm{nt}\end{array}$ & $\begin{array}{c}229 \\
\text { aa }\end{array}$ & $\begin{array}{c}4548 \\
\mathrm{nt}\end{array}$ & $\begin{array}{c}1516 \\
\text { aa }\end{array}$ \\
\hline HTNV 76-118 & 60.2 & 59.4 & 65.4 & 68.2 & 69.1 & 73.3 \\
\hline soov SOO-1 & 59.2 & 60.0 & 65.3 & 67.4 & 68.4 & 73.4 \\
\hline DOBV Greece & 62.7 & 60.6 & 67.8 & 66.9 & 67.7 & 71.5 \\
\hline SEOV 80-39 & 61.9 & 60.0 & 64.6 & 67.8 & 68.2 & 71.9 \\
\hline PUUV Sotkamo & 62.4 & 63.3 & 58.1 & 50.0 & 66.2 & 67.9 \\
\hline TULV 5302v & 62.0 & 63.9 & 58.3 & 50.0 & 65.4 & 67.1 \\
\hline PHV PH-1 & 64.4 & 64.4 & 54.7 & 46.3 & 64.7 & 67.3 \\
\hline SNV NMH10 & 59.3 & 58.1 & 57.7 & 52.9 & 65.7 & 67.0 \\
\hline $\begin{array}{l}\text { ANDV } \\
\text { Chile9717869 }\end{array}$ & 61.4 & 59.2 & 56.9 & 52.9 & 65.4 & 66.5 \\
\hline CBNV CBN-3 & 64.2 & 63.3 & 68.5 & 73.1 & 71.8 & 77.8 \\
\hline ARRV MSB73418 & 60.7 & 62.7 & - & - & 70.4 & 76.1 \\
\hline JMSV MSB144475 & 63.3 & 66.1 & 67.0 & 71.9 & 70.8 & 77.8 \\
\hline SWSV mp70 & 59.8 & 61.7 & 66.7 & 69.4 & 69.3 & 74.7 \\
\hline KKMV MSB148794 & 61.9 & 62.2 & 68.1 & 71.2 & 71.0 & 77.7 \\
\hline RPLV MSB89863 & 51.8 & 44.2 & 64.8 & 65.7 & 69.9 & 74.4 \\
\hline TGNV Tan826 & 63.5 & 62.1 & - & - & 78.7 & 88.3 \\
\hline MJNV Cl05-11 & 53.0 & 47.2 & 54.1 & 45.2 & 61.3 & 61.1 \\
\hline TPMV VRC66412 & 55.1 & 45.5 & 52.3 & 41.5 & 60.9 & 60.8 \\
\hline OXBV Ng1453 & 63.6 & 64.8 & 64.0 & 62.0 & 70.1 & 74.8 \\
\hline ASAV N10 & 62.4 & 63.9 & 64.1 & 65.7 & 71.0 & 76.2 \\
\hline NVAV MSB95703 & 58.1 & 50.3 & 51.8 & 41.0 & 63.6 & 61.3 \\
\hline
\end{tabular}

Abbreviations: ANDV, Andes virus; ARRV, Ash River virus; ASAV, Asama virus; CBNV, Cao Bang virus; DOBV, Dobrava virus; HTNV, Hantaan virus; JMSV, Jemez Spring virus; KKMV, Kenkeme virus; MJNV, Imjin virus; NVAV, Nova virus; OXBV, Oxbow virus; PHV, Prospect Hill virus; PUUV, Puumala virus; RPLV, Camp Ripley virus; SEOV, Seoul virus; SNV, Sin Nombre virus; SOOV, Soochong virus; SWSV, Seewis virus; TGNV, Tanganya virus; TPMV, Thottapalayam virus; TULV, Tula virus. nt, nucleotides; aa, amino acids. from neighboring Guinea and was highly divergent from TPMV and MJNV, two crocidurine shrew-borne hantaviruses from Asia.

In a 540-nucleotide region of the AZGV S segment (GenBank JF276226), the hypothetical nonstructural protein (NSs) open-reading frame, found in arvicolid, neotomine and sigmodontine rodent-borne hantaviruses, was absent. Analysis of a 687-nucleotide region of the AZGV M-genomic segment (GenBank JF276227), which spanned the Gn-Gc juncture, showed the highly conserved WAASA amino acid motif cleavage site at positions 167 to 171 . Potential N-linked glycosylation sites were found at amino acid positions 46, 118 and 142 in the Gn glycoprotein and 179 and 216 in the Gc gylcoprotein. Analysis of the nearly full-length 4,548-nucleotide AZGV L-genomic segment (GenBank JF276228), encoding an incomplete RNA-dependent RNA polymerase of 1,516 amino acids, showed conservation of the five major motifs, designated A, B, C, D and E [38].

Extensive analysis of the available AZGV genome, using multiple recombination-detection methods, including GENECONV, Bootscan, Chimaera, 3SEQ, RDP, SiScan, MaxChi and HyPhy Single Recombinant Breakpoint [39], failed to disclose any evidence of genetic recombination.

\section{Phylogenetic analysis and co-phylogeny mapping}

High bootstrap support for a shared ancestry between AZGV and TGNV, as evidenced by bootstrap values of $>70 \%$ and posterior node probabilities of $>0.70$, was found in phylogenetic trees, based on available $S$ - and L-segment sequences, using the maximum-likelihood (ML) and Bayesian methods (Figure 2). That is, AZGV in the West African pygmy shrew, like TGNV in the Therese's shrew [21], did not form a monophyletic group with TPMV in the Asian house shrew [8] and MJNV in the Ussuri white-toothed shrew [9], which were deeply divergent and basal to other rodent- and soricomorph-borne hantaviruses, with longer branch lengths suggesting greater evolutionary change and possibly older age.

Phylogenetic trees, reconstructed for co-phylogeny mapping using TreeMap 2.0 3 [40], exhibited high bootstrap support for each genomic segment (at both the nucleotide and amino acid levels), with segregation of hantaviruses, according to the Subfamily of their soricomorph reservoir hosts. That is, congruent topologies were found in the host-virus phylogenetic relationships, except for previously reported hantaviruses hosted by two species of shrew moles $[16,17]$.

\section{Biogeographic analyses}

Because the choice of basal taxa can strongly influence the biogeographic reconstruction of the target taxa in 


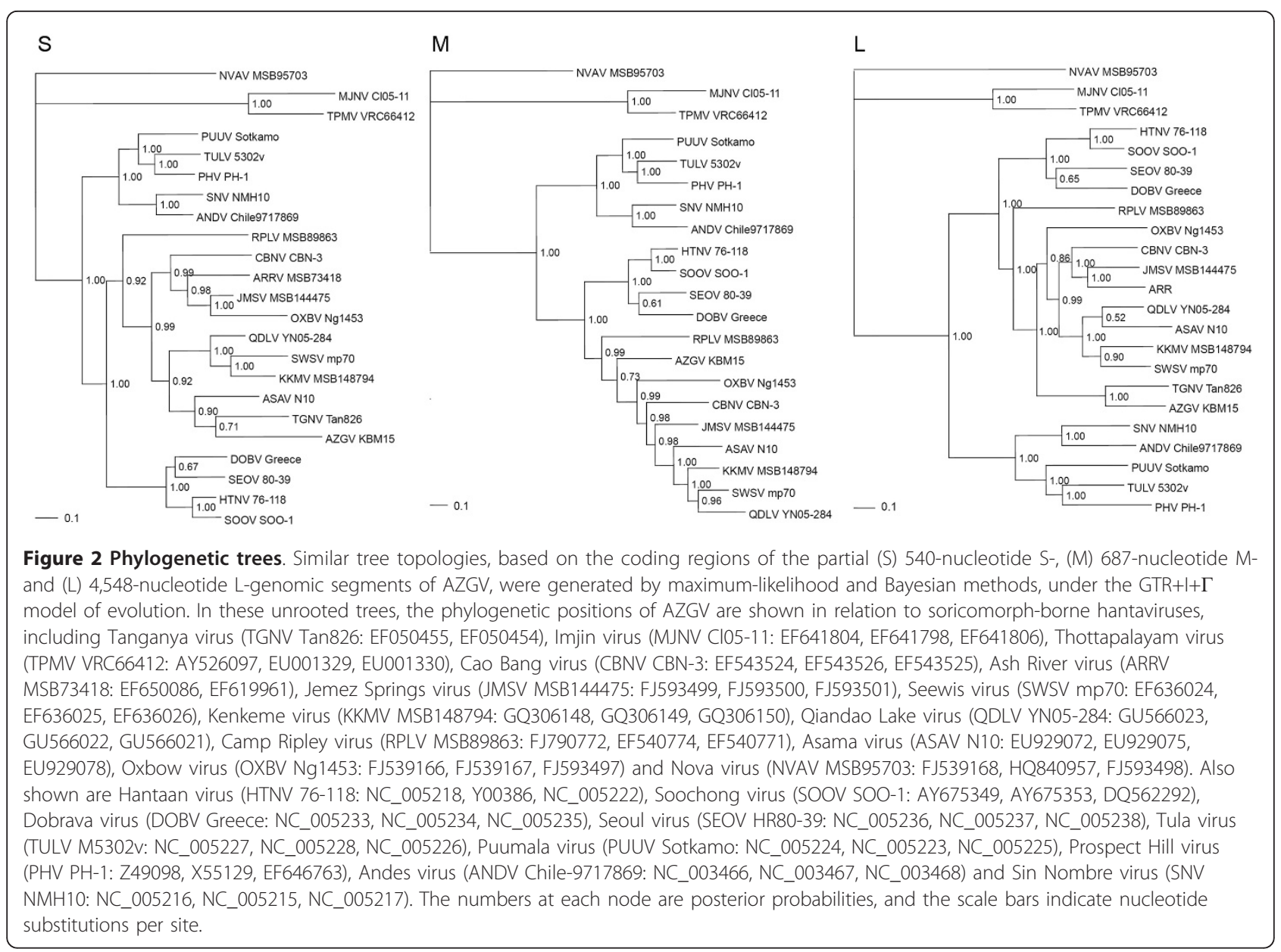

such analyses, the outgroups (Dugbe virus and Rift Valley fever virus) were not included in the analyses. As shown in Figure 3, the common ancestor of all hantaviruses likely emerged in Eurasia rather than Africa (ML support, $87 \%$ ). Moreover, the analyses suggested that the ancestral hosts of hantaviruses may have been members of the Soricomorpha, rather than Rodentia (ML support, $56 \%$ ). However, genomic analyses of many more soricomorph-borne hantaviruses, and studies in search of hantaviruses in other potential reservoir hosts, especially insectivorous bats (Order Chiroptera), are necessary to validate these tentative conclusions.

Biogeographic reconstruction, based on fossil records and assuming equally probable exchanges between continents in both directions, suggests that the Family Soricidae originated in Eurasia [33]. And based on karyologic, paleontologic and molecular genetic data, a Palaearctic-Oriental origin has been proposed for the genus Crocidura, dating to the Upper Miocene (6.8 million years before present) [34]. Moreover, in-depth analysis of 3,560-base pairs of mitochondrial and nuclear DNA of crocidurine shrews from across Eurasia and
Africa, reveals that shrews belonging to the genus Crocidura segregate into an Afrotropical clade, an Asian clade and an Old World clade, which includes Afrotropical, East Palaearctic-Oriental and West Palaearctic species [34]. Crocidura obscurior groups into the Old World clade, while Crocidura theresae, as well as Crocidura buettikoferi, Crocidura jouvenetae and Crocidura olivieri, group in the Afrotropical clade, and Crocidura lasiura in the Asian clade.

Apart from Côte d'Ivoire, the West African pygmy shrew is found in subtropical or tropical moist lowland forests in Ghana, Guinea, Liberia, Sierra Leone and possibly Nigeria. A similar West African distribution is noted for Crocidura buettikoferi and Crocidura jouvenetae, while Crocidura olivieri is far more widespread, from west to east across sub-Saharan Africa [41]. Although previous ecological studies had indicated that Crocidura theresae, the presumed reservoir of TGNV, is widespread and abundant in Côte d'Ivoire [42,43], this crocidurine shrew species was not captured during any of our multiple trapping expeditions. As such, we were unable to confirm the presence of TGNV in the 


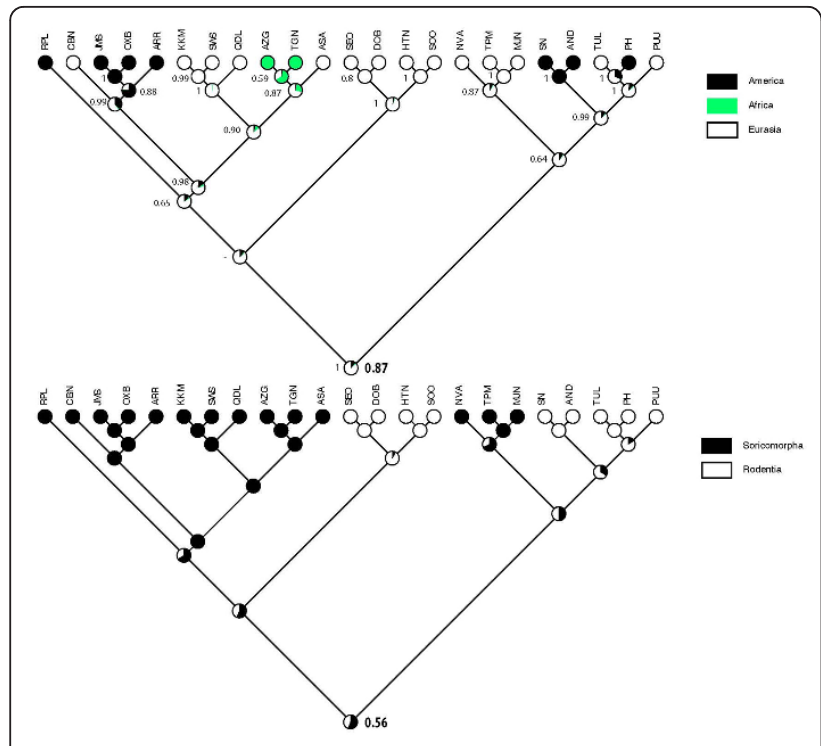

Figure 3 Phylogenetic distribution and reconstruction. Phylogenetic distribution and reconstruction of ancestral states for (A) the biogeographic origin (America, Eurasia or Africa) and (B) the host (Soricomorpha or Rodentia) of hantaviruses using Mesquite 2.74 (with a representation of ML supports for each state and node, and ML support [in bold] for the basal nodes). Bayesian posterior probabilities from BEAST are shown for each node in (A).

Therese's shrew or to analyze the genetic diversity and phylogeography of TGNV.

In this regard, future studies are warranted to confirm that the West African pygmy shrew is the true reservoir host of AZGV. Also, whole genome sequence analysis of many more hantaviruses from sub-Saharan Africa are required to gain a better understanding about how the biogeographic origin and radiation of African shrews might have contributed to, or have resulted from, the evolution and cross-species transmission of hantaviruses. Intensified efforts are underway in search of hantaviruses in other shrew species, including Myosorex and Sylvisorex shrews, which are not found elsewhere and are unique to Africa. Meanwhile, the disproportionately high number of hantaviruses hitherto discovered in soricomorphs over a relatively brief period of searching, and the far greater genetic diversity of shrew- and moleborne hantaviruses, compared to those harbored by rodents, provide additional support for the emerging concept that soricomorphs may have served as the early reservoirs of ancestral hantaviruses.

\section{Acknowledgements}

We thank the director of the Ivorian National Park Office and Dr. Souleymane Konate, director of the Lamto Natural Reserve, for permission to conduct studies in protected sites. Also, we thank Professor Christiane Denys for supporting the field work. Financial support for this research was provided in part by U.S. Public Health Service grant R01A1075057 from the National Institute of Allergy and Infectious Diseases, and grants P20RR018727 and G12RR003061 from the National Center for Research Resources, National Institutes of Health.

\section{Author details}

'John A. Burns School of Medicine, University of Hawaii at Manoa, Honolulu, HI 96813, USA. ${ }^{2}$ Department of Biology, Université de Cocody, Abidjan, Côte d'Ivoire. ${ }^{3}$ School of Biological Sciences, University of Sydney, New South Wales 2006, Australia. ${ }^{4}$ Department Systématics and Evolution, Muséum National d'Histoire Naturelle, Paris, France.

\section{Authors' contributions}

HJK performed the RNA extraction, RT-PCR, and genetic and phylogenetic analyses. BK and FJ conducted the field expeditions and provided the background data on wild-caught shrews. SD conducted the biogeographic analysis and data interpretation. RY conceived the research design, arranged the collaboration and provided scientific oversight. All authors read and approved the final manuscript.

\section{Competing interests}

The authors declare that they have no competing interests.

Received: 22 June 2011 Accepted: 28 July 2011 Published: 28 July 2011

\section{References}

1. Van Heuverswyn F, Peeters M: The origins of HIV and implications for the global epidemic. Curr Infect Dis Rep 2007, 9:338-346.

2. Sharp PM, Hahn BH: The evolution of HIV-1 and the origin of AIDS. Philos Trans R Soc Lond B Biol Sci 2010, 365:2487-2494.

3. Leroy EM, Kumulungui B, Pourrut $X$, Rouquet $P$, Hassanin $A$, Yaba $P$, Délicat A, Paweska JT, Gonzalez JP, Swanepoel R: Fruit bats as reservoirs of Ebola virus. Nature 2005, 438:575-576.

4. Biek R, Walsh PD, Leroy EM, Real LA: Recent common ancestry of Ebola Zaire virus found in a bat reservoir. PLoS Pathog 2006, 2:e90.

5. Frame JD, Baldwin JM Jr, Gocke DJ, Troup JM: Lassa fever, a new virus disease of man from West Africa. I. Clinical description and pathological findings. Am J Trop Med Hyg 1970, 19:670-676.

6. Briese T, Paweska JT, McMullan LK, Hutchison SK, Street C, Palacios G, Khristova ML, Weyer J, Swanepoel R, Egholm M, Nichol ST, Lipkin WI: Genetic detection and characterization of Lujo virus, a new hemorrhagic fever-associated arenavirus from Southern Africa. PLoS Pathog 2009, 4 e1000455.

7. Carey DE, Reuben R, Panicker KN, Shope RE, Myers RM: Thottapalayam virus: a presumptive arbovirus isolated from a shrew in India. Indian J Med Res 1971, 59:1758-1760.

8. Yadav PD, Vincent MJ, Nichol ST: Thottapalayam virus is genetically distant to the rodent-borne hantaviruses, consistent with its isolation from the Asian house shrew (Suncus murinus). Virol J 2007, 4:80.

9. Song JW, Kang HJ, Gu SH, Moon SS, Bennett SN, Song KJ, Baek LJ, Kim HC, O'Guinn ML, Chong ST, Klein TA, Yanagihara R: Characterization of Imjin virus, a newly isolated hantavirus from the Ussuri white-toothed shrew (Crocidura lasiura). J Virol 2009, 83:6184-6191.

10. Song JW, Kang HJ, Song KJ, Truong TT, Bennett SN, Arai S, Truong NU, Yanagihara R: Newfound hantavirus in Chinese mole shrew, Vietnam. Emerg Infect Dis 2007, 13:1784-1787.

11. Song JW, Gu SH, Bennett SN, Arai S, Puorger M, Hilbe M, Yanagihara R: Seewis virus, a genetically distinct hantavirus in the Eurasian common shrew (Sorex araneus). Virol J 2007, 4:114.

12. Kang HJ, Arai S, Hope AG, Song JW, Cook JA, Yanagihara R: Genetic diversity and phylogeography of Seewis virus in the Eurasian common shrew in Finland and Hungary. Virol J 2009, 6:208.

13. Arai S, Bennett SN, Sumibcay L, Cook JA, Song JW, Hope A, Parmenter C, Nerurkar VR, Yates TL, Yanagihara R: Phylogenetically distinct hantaviruses in the masked shrew (Sorex cinereus) and dusky shrew (Sorex monticolus) in the United States. Am J Trop Med Hyg 2008, 78:348-351.

14. Kang HJ, Arai S, Hope AG, Cook JA, Yanagihara R: Novel hantavirus in the flat-skulled shrew (Sorex roboratus). Vector Borne Zoonotic Dis 2010, 10:593-597.

15. Arai S, Song JW, Sumibcay L, Bennett SN, Nerurkar VR, Parmenter C, Cook JA, Yates TL, Yanagihara R: Hantavirus in northern short-tailed shrew, United States. Emerg Infect Dis 2007, 13:1420-1423. 
16. Arai S, Ohdachi SD, Asakawa M, Kang HJ, Mocz G, Arikawa J, Okabe N, Yanagihara R: Molecular phylogeny of a newfound hantavirus in the Japanese shrew mole (Urotrichus talpoides). Proc Natl Acad Sci USA 2008, 105:16296-16301.

17. Kang HJ, Bennett SN, Dizney L, Sumibcay L, Arai S, Ruedas LA, Song JW, Yanagihara R: Host switch during evolution of a genetically distinct hantavirus in the American shrew mole (Neurotrichus gibbsii). Virology 2009, 388:8-14.

18. Kang HJ, Bennett SN, Sumibcay L, Arai S, Hope AG, Mocz G, Song JW Cook JA, Yanagihara R: Evolutionary insights from a genetically divergent hantavirus harbored by the European common mole (Talpa europaea). PLoS One 2009, 4:e6149.

19. Kang HJ, Bennett SN, Hope AG, Cook JA, Yanagihara R: Shared ancestry between a mole-borne hantavirus and hantaviruses harbored by cricetid rodents. J Virol 2011, 85:7496-7503.

20. Klempa B, Fichet-Calvet E, Lecompte E, Auste B, Aniskin V, Meisel H, Denys $C$, Koivogui L, ter Meulen J, Krüger DH: Hantavirus in African wood mouse, Guinea. Emerg Infect Dis 2006, 12:838-840.

21. Klempa B, Fichet-Calvet E, Lecompte E, Auste B, Aniskin V, Meisel H, Barrière $P$, Koivogui $L$, ter Meulen J, Krüger $D H$ : Novel hantavirus sequences in shrew, Guinea. Emerg Infect Dis 2007, 13:520-522.

22. Combet C, Blanchet C, Geourjon C, Deléage G: NPS@: Network Protein Sequence Analysis. Trends Biochem Sci 2000, 25:147-150.

23. Gavel $Y$, von Heijne G: Sequence differences between glycosylated and non-glycosylated Asn-X-Thr/Ser acceptor sites: implications for protein engineering. Protein Eng 1990, 3:433-442.

24. Krogh A, Larsson B, von Heijne G, Sonnhammer EL: Predicting transmembrane protein topology with a hidden Markov model: application to complete genomes. J Mol Biol 2001, 305:567-580.

25. Thompson JD, Higgins DG, Gibson TJ: CLUSTAL W: improving the sensitivity of progressive multiple sequence alignment through sequence weighting, position-specific gap penalties and weight matrix choice. Nucleic Acids Res 1994, 22:4673-4680.

26. Bininda-Emonds OR: transAlign: using amino acids to facilitate the multiple alignment of protein-coding DNA sequences. BMC Bioinformatics 2005, 6:156.

27. Swofford D: PAUP*: Phylogenetic Analysis Using Parsimony (*and Other Methods). Sunderland, Massachusetts: Sinauer Associates; 2003.

28. Stamatakis A, Hoover P, Rougemont J: A rapid bootstrap algorithm for the RAxML web servers. Syst Biol 2008, 57:758-771.

29. Ronquist F, Huelsenbeck JP: MrBayes 3: Bayesian phylogenetic inference under mixed models. Bioinformatics 2003, 19:1572-1574.

30. Posada D: jModelTest: Phylogenetic Model Averaging. Mol Biol Evol 2008, 25:1253-1256.

31. Maddison WP, Maddison DR: Mesquite: a modular system for evolutionary analysis. 2010 [http://mesquiteproject.org], Version 2.74.

32. Lewis PO: A likelihood approach to estimating phylogeny from discrete morphological character data. Syst Biol 2001, 50:913-925.

33. Dubey S, Salamin N, Ohdachi SD, Barrière P, Vogel P: Molecular phylogenetics of shrews (Mammalia: Soricidae) reveals timing of transcontinental colonizations. Mol Phylogenet Evol 2007, 44:126-137.

34. Dubey S, Salamin N, Ruedi M, Barrière P, Colyn M, Vogel P: Biogeographic origin and radiation of the Old World crocidurine shrews (Mammalia: Soricidae) inferred from mitochondrial and nuclear genes. Mol Phylogenet Evol 2008, 48:953-963.

35. Drummond AJ, Rambaut A: BEAST v1.4. 2006 [http://beast.bio.ed.ac.uk/]

36. Drummond AJ, Ho SYW, Rawlence N, Rambaut A: A Rough Guide to BEAST 1.4. 2007 [http://beast.bio.ed.ac.uk].

37. Rambaut A, Drummond AJ: Tracer v1.4. 2007 [http://beast.bio.ed.ac.uk/ Tracer].

38. Kukkonen SK, Vaheri A, Plyusnin A: L protein, the RNA-dependent RNA polymerase of hantaviruses. Arch Virol 2005, 150:533-556.

39. Pond SL, Frost SDW, Muse SV: HyPhy: hypothesis testing using phylogenies. Bioinformatics 2005, 21:676-679.

40. Charleston MA, Page RDM: TreeMap 2.0b. Macintosh program for cophylogenetic analysis, 2.0b ed. 1998.

41. Dubey $S$, Antonin M, Denys $C$, Vogel P: Use of phylogeny to resolve the taxonomy of the widespread and highly polymorphic African giant shrews (Crocidura olivieri group, Crocidurinae, Mammalia). Zoology 2007, 110:48-57.
42. Kadjo B: Peuplement en Rongeurs dans quatre milieux de savane préforestière de Lamto, Côte d'Ivoire. Mémoire de DEA 1992, 71

43. Kadjo B, Dosso H, Vuattoux R: Influence de la végétation sur le peuplement des rongeurs dans la région centre de Côte d'Ivoire. Agronomie Africaine 1996, 8:169-180.

\section{doi:10.1186/1743-422X-8-373}

Cite this article as: Kang et al:: Molecular evolution of Azagny virus, a newfound hantavirus harbored by the West African pygmy shrew (Crocidura obscurior) in Côte d'Ivoire. Virology Journal 2011 8:373.

\section{Submit your next manuscript to BioMed Central and take full advantage of:}

- Convenient online submission

- Thorough peer review

- No space constraints or color figure charges

- Immediate publication on acceptance

- Inclusion in PubMed, CAS, Scopus and Google Scholar

- Research which is freely available for redistribution

Submit your manuscript at www.biomedcentral.com/submit
C Biomed Central 